\title{
Estimates of heterozygosity in two social insects using a large number of electrophoretic markers
}

\author{
D. DEWAYNE SHOEMAKER, JAMES T. COSTA III \& KENNETH G. ROSS \\ Department of Entomology, University of Georgia, Athens, GA 30602, U.S.A.
}

\begin{abstract}
An extensive electrophoretic survey of enzyme and protein markers was conducted for a haplodiploid eusocial insect, the red imported fire ant (Solenopsis invicta), and for a diploid communal insect, the eastern tent caterpillar (Malacosoma americanum). This survey resulted in the discovery of 110 electrophoretic loci for $S$. invicta (15 of which were polymorphic at the 95 per cent level) and 37 electrophoretic loci for $M$. americanum (seven polymorphic). Expected heterozygosities (mean $H_{\exp } \pm$ S.E.) were $0.051 \pm 0.013$ and $0.092 \pm 0.030$ for $S$. invicta and $M$. americanum, respectively. Although these values do not differ significantly, they are consistent with the frequently reported pattern of low gene diversity in the eusocial Hymenoptera relative to noneusocial diploid insects. This pattern persists when a large number of markers is scored in different life stages and castes, as in $S$. invicta in this study, and when a direct comparison is made using data generated in a single laboratory.
\end{abstract}

Keywords: electrophoresis, fire ant, gene diversity, heterozygosity, Malacosoma americanum, Solenopsis invicta, tent caterpillar.

\section{Introduction}

Eusocial Hymenoptera generally display lower levels of genetic variation at enzyme-encoding loci than other insects (Snyder, 1974; Metcalf et al., 1975; Pamilo et al., 1978). Various explanations for the paucity of genetic variation in these insects have been proposed. Those that focus upon the intrinsic properties of haplodiploidy include increased selection due to hemizygous expression of deleterious recessive alleles in males, increased genetic drift due to the reduced effective population sizes associated with male haploidy, and reduced recombination rates (Crozier, 1970; Pamilo \& Crozier, 1981). Other explanations focus on the population-level consequences of eusociality. These include the possibilities that buffered environmental conditions in the colony reduce any fitness benefits from overdominance (Synder, 1974), that the mating systems of eusocial Hymenoptera lower gene diversity through inbreeding (Berkelhamer, 1983), or that low effective population sizes stemming from the presence of non-reproductive castes enhance the role of drift (Graur, 1985).

Genetic studies of eusocial Hymenoptera have proved to be difficult to undertake as a result of this lack of abundant protein polymorphism (Packer \& Owen, 1992). Yet, included among the eusocial Hymenoptera are the most appropriate species for addressing certain population genetics problems, such as the importance of family structure in determining the distribution of genetic variation and the potential role of kin selection in social evolution (Hamilton, 1964; Michod, 1982; Wade, 1985; Ross \& Carpenter, 1991; Packer \& Owen, 1992). Thus, an important task for social insect researchers is to develop techniques to circumvent the problem of low gene diversity in these insects.

In this paper we describe an electrophoretic study in which we have substantially increased the number of available polymorphic protein markers in the red imported fire ant (Solenopsis invicta) by employing a large number of stains, systematically varying experimental conditions, and using different life stages and castes as source material. The unprecedented number of markers that we are now able to survey in this eusocial species allows us to address two important questions. First, does increasing the number of loci studied by over fourfold from the number previously available appreciably affect the estimate of heterozygosity for this species? This question is of interest 
because most estimates of heterozygosity are based on relatively few loci, yet theoretical studies show that estimates based on large numbers of loci most accurately reflect genomic variation (Nei, 1978; Mitton \& Pierce, 1980; Chakraborty, 1981). Second, is the estimate based on this larger set of loci representative of the low estimates of heterozygosity for other eusocial Hymenoptera, these other estimates typically having been generated using far smaller numbers of loci from single life stages of single castes? To provide additional insight into this latter problem, we also present an estimate of heterozygosity for a non-eusocial (though communal) diploid insect, the eastern tent caterpillar (Malacosoma americanum), based on data generated using a protocol identical to that used for the fire ants. In comparing estimates between the two species we can rule out the effects of between-laboratory variation in methodologies, so that any observed differences in gene diversity are most reasonably attributed to real biological differences between the species (Simon \& Archie, 1985).

\section{Materials and methods}

\section{Sample collections}

Sixty queenright monogyne fire ant colonies were collected from a wide geographical area encompassing north-east Georgia, U.S.A. This sampling protocol was designed to ensure adequate representation of the genetic diversity present within $S$. invicta in North America (see Ross et al., 1987). The ants were returned to the laboratory in five-gallon buckets and were removed from the soil by flooding (Jouvenaz et al., 1977) and transferred to artificial nests in plastic trays. Colonies were maintained in the laboratory in these nests and fed an artificial diet supplemented with crickets (Banks et al., 1981; Ross \& Fletcher, 1985).

Overwintering egg masses of eastern tent caterpillars were collected from an area in north-east Georgia comparable in size to that from which the fire ants were collected. Egg masses were maintained in the laboratory at $5^{\circ} \mathrm{C}$ and 80 per cent $\mathrm{RH}$ until eclosion (Bucher, 1959). Colonies were allowed to eclose in Petri dishes and reared in isolation on fresh leaves of their favoured host tree, black cherry (Prunus serotina).

\section{Electrophoretic techniques}

We reviewed the literature to obtain a large number of staining recipes that did not involve the use of unduly expensive chemicals (references in Appendix 1). A total of 95 stains were employed to survey enzyme or protein activity in both species. Both the worker and queen castes (females) were used as source material for protein extraction in the fire ants. The worker caste was surveyed using fourth instar larvae, pupae, and adults, whereas only pupae and adults of the queen caste were surveyed (female reproductives cannot be distinguished from males until the pupal stage). The use of different life stages of fire ants was important because previous studies of social Hymenoptera have focused almost exclusively on adults, yet different patterns of isozyme expression in different life stages are common in holometabolous insects (e.g. Wagner \& Selander, 1974; Berlocher, 1984; Singh \& Rhomberg, 1987). The thorax (mesosoma) and gaster of adults of both castes were used separately as source material because preliminary work in our laboratory revealed that this procedure yields superior resolution of staining bands for many of the markers. For the eastern tent caterpillar, the entire soma of third or fourth instar larval individuals of either sex was used as the source material for protein extraction. Pupae and adults of this species were not included in this study because of the difficulty in securing large, geographically representative sample sizes comparable to those of the larvae.

Electrophoresis was conducted on horizontal gels of 14 per cent starch (Ross \& Fletcher, 1985; Ross et al., 1987). For the fire ants, four individuals from each caste and life stage described above were initially surveyed using each stain recipe and four different buffer systems (see Appendix 1 and Ross et al., 1985 for references). All potential markers generated from this initial survey were further screened for consistency of expression and formation of discrete, well-resolved bands, as well as for the presence of variable banding patterns, using single individuals from each of 32 nests. Only single individuals per nest were used in this second survey to maximize the probability of discovering polymorphisms; monogyne fire ant nests represent families of closely related individuals in which the genotypes are not independent (Ross \& Fletcher, 1985).

Similar staining recipes were used on the same day to avoid redundancy in the scoring of the markers. Such redundancy can occur because related stains sometimes reveal the same enzyme product (Richardson et al., 1986). Patterns of expression across the various life stages and castes were also informative with respect to redundancy of the markers. As a final check against repeated scoring of the same loci, banding patterns of $S$. invicta were compared to those of the congener $S$. richteri [and to those of several other congeners for a subset of 26 of the loci (Ross \& Trager, 1990)]. These comparisons were useful in assigning locus homologies across stains and for determining whether multiple bands produced by single stains were 
the products of multiple loci. In spite of these precautions it is likely that some small proportion of the monomorphic loci described for S. invicta actually have been stained and scored more than once in this study.

Essentially the same survey protocols were used for the eastern tent caterpillars (except for the comparisons across life stages and species). As with the fire ants, only one individual per colony was scored for each locus during the survey for polymorphisms due to significant family structuring and the resulting nonindependence of genotypes from single colonies (Costa \& Ross, 1992).

Mendelian inheritance of putative polymorphic markers in both species was confirmed in two ways. First, family studies were conducted for all markers. Twenty to 50 individuals from each of 27-46 fire ant colonies were chosen at random and their genotypes determined at each polymorphic locus. Previous work has shown that monogyne fire ant colonies represent simple families, that is families in which all the offspring in a colony are the progeny of a single female mated to a single haploid male (Ross \& Fletcher, 1985). Thus, only two types of genotypic distributions are expected for Mendelian markers in nestmate females: either one genotypic class of females is present or there are two classes present, at least one of which is the heterozygous class. If two genotypic classes are present these are expected to segregate in a 1:1 ratio. Genotypic ratios at each locus for each family with segregating genotypes were tested for deviations from this expected 1:1 ratio using the binomial test.

Colony genetic composition has not been studied previously in eastern tent caterpillars. Thirty to 100 individuals from each of 48 colonies were chosen at random and their genotypes at each polymorphic locus were identified. Genotypic ratios for each locus in each segregating colony were tested for deviation from the ratios expected under a simple family model, wherein all caterpillars in a colony are full siblings, using either the binomial test or chi-square test (depending on the number of genotypic classes present).

The second method of confirming Mendelian inheritance, employed for all polymorphic loci except two in $S$. invicta with null alleles, was to test for conformation of observed population genotypic frequencies to those expected under Hardy-Weinberg equilibrium. To estimate allele and genotypic frequencies for these tests a resampling procedure was used whereby single genotypes were drawn at random 50 times (with replacement) from each of the nests used in the family studies of $S$. invicta, and from 37 of the nests used in the family studies of $M$. americanum. Allele frequencies were then estimated as the means of the allele frequencies in the 50 resampled genotypic distributions. This procedure yields an unbiased estimate of population allele frequencies in strongly family-structured populations in which many individuals have been sampled per family (e.g. Crozier et al., 1987; Schwarz, 1988; Ross \& Matthews, 1989). The mean allele frequencies were used to estimate the frequencies of genotypes expected under Hardy-Weinberg equilibrium, and each of the 50 resampled genotypic distributions for each locus was then tested for concordance to these Hardy-Weinberg distributions using chi-square tests with Yates'; continuity correction (Weir, 1990).

Expected heterozygosity $\left(H_{\text {exp }}\right)$ or gene diversity for $S$. invicta and $M$. americanum was calculated from equation 8.4 of $\mathrm{Nei}$ (1987) using allele frequencies generated by the resampling procedure or, in the case of two loci in $S$. invicta, with null alleles, by the maximum likelihood procedure of Halliday (1979), which is based on distributions of phenotypes within families. The variance of $H_{\exp }$ was estimated by jackknifing across the individual-locus heterozygosity values $\left(h_{\text {exp }}\right)$. It was of interest to determine if the new $H_{\text {exp }}$ values generated for these two species were comparable to values reported for other species in related groups. To this end, $H_{\text {exp }}$ values for diploid non-eusocial insects, for Lepidoptera only, and for eusocial Hymenoptera were extracted from the literature. Mean $H_{\text {exp }}$ values for these groups were estimated using only a single value per genus (the average of the reported values for congeneric species), thus avoiding giving undue weight to taxa in which several closely related species have been studied (Ridley, 1983, 1989; Crespi, 1991). Variances were generated by jackknifing across these singlegenus values. The jackknife variances were in all cases used to construct 95 per cent confidence intervals about the means by assuming the $t$-distribution.

\section{Results}

All electrophoretic loci revealed in this study of $S$. invicta and $M$. americanum are listed in Appendices 1 and 2, respectively. A total of 110 putative loci were revealed for the fire ants, 15 of which were polymorphic at the 95 per cent level (i.e. frequency of the most common allele $<0.95 ; P=0.136)$. For the eastern tent caterpillar, we were able to visualize and confidently score the products of 37 putative loci, seven of which were polymorphic at the 95 per cent level $(P=0.189)$.

Mendelian inheritance was confirmed for all putative polymorphic markers. Family studies showed that colonies segregating for different genotypes exhibited genotypic ratios that conform to Mendelian expectations in nearly all cases. Only 3 per cent of the 
comparisons for $S$. invicta involved genotypic ratios that deviated significantly from $1: 1$ at the 5 per cent level. Furthermore, fewer than 5 per cent of the comparisons at any single polymorphic marker exhibited significant deviations. Similarly, less than 5 per cent of the genotypic distributions in segregating colonies of $M$. americanum exhibited deviations from expected Mendelian ratios of the genotypes and, again, the few significant deviations observed were distributed across many markers. Finally, the identities of genotypic classes within families of both species were fully consistent with the expectations of Mendelian inheritance.

Further evidence of Mendelian inheritance of the putative polymorphic markers comes from comparisons of observed population genotypic distributions with those expected under Hardy-Weinberg equilibrium. For both species fewer than 5 per cent of the resampled genotypic distributions for each marker differed significantly from the expected distribution $(\alpha=0.05)$. Thus, analyses of family structure and population genotypic frequencies both indicate that the polymorphic markers revealed in this study are the products of single Mendelian loci.

The expected heterozygosity $\left(H_{\exp } \pm\right.$ S.E. $)$ for $S$. invicta, based on all 110 loci, is $0.051 \pm 0.013$. This value is not significantly different from our previous estimate of $H_{\text {exp }}$ for populations from Georgia and north Florida, U.S.A. $(0.044 \pm 0.025)$, which was based on a subset of only 26 of these loci (Ross \& Trager, 1990). While $H_{\text {exp }}$ of fire ants based on 110 loci falls just outside of the high end of the 95 per cent confidence interval for values reported for other eusocial Hymenoptera, this value is nonetheless well below the 95 per cent confidence interval for diploid non-euso- cial insects (Fig. 1). The expected heterozygosity for $M$. americanum is $0.092 \pm 0.030$. Although this value is significantly lower than previously reported values for other Lepidoptera, it is not significantly different from previous estimates obtained for diploid non-eusocial insects, although it is at the low end of the range of values (Fig. 1). The 95 per cent confidence intervals about the values of $H_{\text {exp }}$ for $S$. invicta and $M$. americanum overlap considerably.

The observation that $H_{\text {exp }}$ in fire ants, based on 110 loci, was very similar to the value based on a subset of only 26 loci led us to consider the statistical consequences of sampling variable numbers of loci (see also Nei \& Roychoudhury, 1974; Archie, 1985). To illustrate the effect of varying the number of loci sampled on the precision of heterozygosity estimates, a randomization procedure was employed to resample subsets of loci from the complete fire ant gene diversity dataset. A number $(L)$ of these loci was resampled 100 times and the range of $H_{\exp }$ values estimated from the resampled loci was identified (Fig. 2). This resampling technique is relatively unbiased in that each iteration at each level of $L$ is a random sample of loci (with each locus represented only once in a given iteration) and each level of $L$ is independent of every other. The range in estimated $H_{\text {exp }}$ values (and associated variance) decreases dramatically as one increases the number of loci sampled from 1 to 10 , and thereafter decreases relatively gradually with subsequent increases in the number of loci (Fig. 2, left panel). Thus, while an estimate of $H_{\text {exp }}$ close to the assumed population value of $H_{\text {exp }}$ for fire ants might be obtained by sampling even relatively small numbers of loci, reasonable certainty in this estimate is afforded only with larger numbers of
Fig. 1. Expected heterozygosities $\left(H_{\text {ewp }}\right)$ for several insect groups as reported in the literature (Graur, 1985; Packer \& Owen, 1990, 1992; Crespi, 1991; L. Packer \& R. E. Owen, unpublished data) and for $S$. invicta and $M$. americanum (this study). Bars represent the 95 per cent confidence intervals generated by jackknifing across single-genus heterozygosity values (solid bars) or across single-locus heterozygosity values (dashed bars). Numbers in parentheses indicate numbers of genera represented in each group.

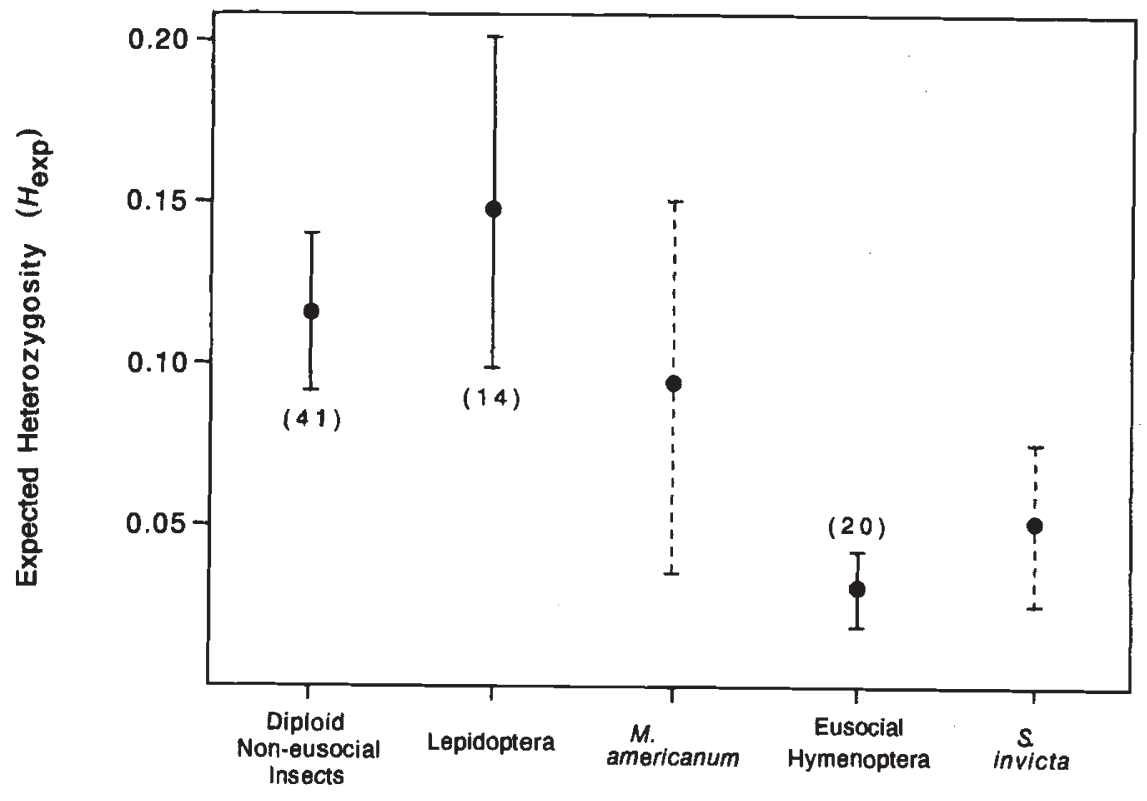




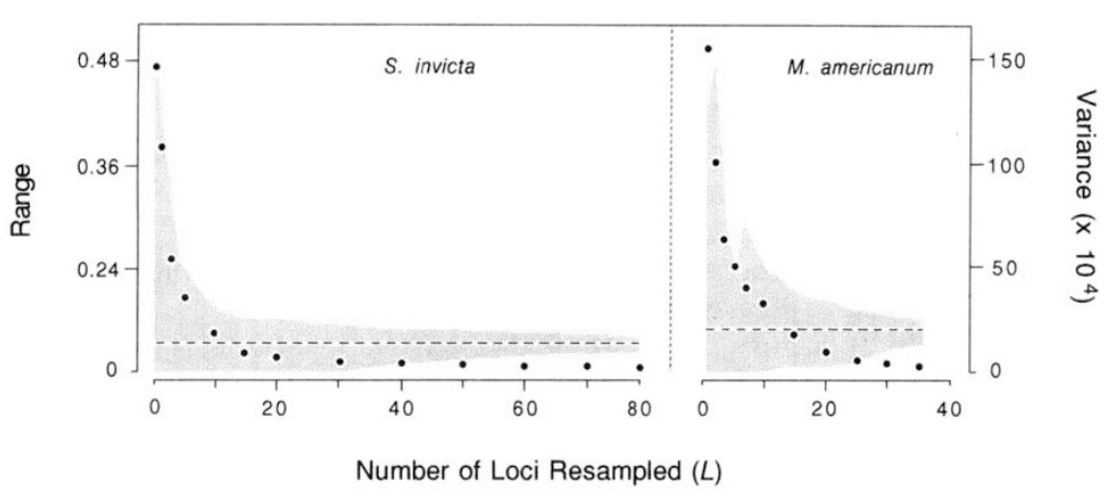

Fig. 2. Range (shading) and variance (dots) of $H_{\text {exp }}$ values estimated from randomly drawn subsets of the electrophoretic loci studied in $S$, invicta and $M$. americanum. Each number or subset of loci was resampled independently (with replacement) 100 times. Dashed lines represent values of $H_{\text {exp }}$ estimated from the entire sets of 110 (S. invicta) and 37 (M. americanum) loci. sampled loci (cf. Gorman \& Renzi, 1979; Singh \& Rhomberg, 1987). The precision of the fire ant $H_{\exp }$ estimates improves as the number of loci studied increases from 26 to 110 , as expected (Nei \& Roychoudhury, 1974), but this improvement is only modest compared to that seen between, say, five and 15 loci. Thus, it is not surprising that our estimates of $H_{\text {exp }}$, based on 26 and 110 loci, are similar. It should be pointed out that the relationships shown in Fig. 2 for $S$. invicta are not general; the precise shape of the variance curve and progressive decrease in range of estimates is unique to the particular pattern of variation across loci in the fire ant dataset. This is evident from a comparison of the $S$. invicta graph with one generated for $M$. americanum using the same resampling procedure (Fig. 2, right panel).

\section{Discussion}

The eusocial Hymenoptera have long been reported to be depauperate in genetic variation at enzyme-encoding loci (Metcalf et al., 1975; Pamilo et al., 1978). Regardless of the intrinsic or extrinsic mechanisms underlying this lack of diversity, it is of interest to social insect researchers to circumvent the problem that it presents for studies that require polymorphic markers. We have shown that several simple refinements of standard electrophoretic procedures, including the screening of a large number of enzymes and the use of sequential electrophoresis in which the buffer systems are varied, greatly increases the number of polymorphic markers we can study in fire ants (from three to 15-Ross et al., 1987; Ross \& Trager, 1990). Perhaps the most important technique applied in this study, however, is the use of different life stages and castes as source material. Previous studies also have demonstrated differential expression of certain enzyme systems in different life stages of holometabolous insects (Wagner \& Selander, 1974; Singh \& Rhomberg, 1987), so that inclusion of all life stages of these insects, when possible, can be expected to greatly increase the number of useful markers available.
The pattern of somewhat higher gene diversity in Solenopsis invicta, relative to other eusocial Hymenoptera, that was suggested by our earlier studies persists with the larger number of markers employed in this study. This implies that there may be real differences in gene diversity between this species and other eusocial Hymenoptera or, alternatively, that there is some favourable bias in our ability to uncover polymorphisms. Regardless of what accounts for this difference, it is important to note that the expected heterozygosity reported for fire ants still falls far short of that generally found in non-eusocial diploid insects. Hence, the generality of the phenomenon of low gene diversity in eusocial Hymenoptera compared to other insects receives further support from our data.

One reason for including a non-eusocial diploid insect in this study was to eliminate inter-laboratory variation as a source of the differences in $H_{\text {exp }}$ between eusocial Hymenoptera and other insects in previous estimates (Simon \& Archie, 1985; Packer \& Owen, 1992). Although the expected heterozygosities did not differ significantly between $S$. invicta and $M$. americanum, the value of $H_{\exp }$ for the eastern tent caterpillars is representative of that for diploid insects, whereas $H_{\text {exp }}$ for the fire ants is not. Furthermore, because $H_{\text {exp }}$ is relatively low for both species, the associated high interlocus variance in $h_{\exp }$ may make real biological differences difficult to discern (Archie, 1985). The value of $H_{\text {exp }}$ for $M$. americanum falls at the low end of the range of values previously reported for Lepidoptera, which may be due to a downward bias stemming from our stringent requirements for including loci in the analyses. Although a substantial proportion of the total potential markers found in these caterpillars displayed variable banding patterns, many of these were abandoned early in the study because this variation proved to be uninterpretable. The frequency with which this situation arises increases with an increase in the proportion of loci that are polymorphic, so that the downward bias in $H_{\text {exp }}$ may be expected to be more significant in species with higher $H_{\text {exp }}$ (e.g. $M$. americanum) than in species with lower $H_{\exp }$ (e.g. $S$. 
invicta). It is possible that other studies of Lepidoptera and other diploid insects that do not confirm Mendelian inheritance of the products of putative polymorphic loci may systematically inflate their reported $H_{\text {exp }}$ values to a greater extent than do studies of insects with lower values of $H_{\text {exp }}$.

One confounding factor in our study is that $S$. invicta is an introduced species in the U.S.A. It is possible, therefore, that our study population does not exhibit gene diversity representative of native populations because of a recent population bottleneck. However, comparison of our data with those obtained by Ross \& Trager (1990) for native South American populations of this species reveals that values of $H_{\text {exp }}$, based on identical subsets of $26 \mathrm{loci}$, are indistinguishable $\langle 0.052 \pm 0.027$ vs. $0.052 \pm 0.025$ for introduced and native populations, respectively).

In conclusion, this study provides the most comprehensive genetic data available for a single species of eusocial hymenopteran, and these data suggest that heterozygosity is lower in this ant than in typical noneusocial diploid insects. It will be of interest to determine if the phenomenon of low gene diversity in the eusocial Hymenoptera is confined to loci encoding soluble proteins (usually enzymes) or whether it is a genomic-wide phenomenon. With the advent of new molecular techniques, the answer to this question should be close at hand.

\section{Acknowledgements}

We would like to thank M. L. Arnold and L. Packer for comments on the manuscript and L. Packer and R. E. Owen for providing unpublished results. This research was supported in part by a grant from the National Geographic Society to K. G. Ross and E. L. Vargo, NSF Grant BSR-8901373 to K. G. Ross and J. T. Costa, Sigma Xi Grants-in-Aid of Research to J. T. Costa, and USDA Molecular Entomology Training Grant 10-11-RH174-105 to A. O. Lea and L. K. Miller.

\section{References}

ARCHIE, J. W. 1985. Statistical analysis of heterozygosity data: Independent sample comparisons. Evolution, 39, 623-637.

ASHTON, G. C. 1965. Serum amylase (thread protein) polymorphism in cattle. Genetics, 51, 431-437.

BANKS, W. A., LOFGREN, C. S., JOUVENAZ, D. P., STRINGER, C. E., BISHOP, P. M., WILLIAMS, D. F., WOJCIK, D. P. AND GLANCEY, B. M. 1981. Techniques for Collecting, Rearing, and Handling Imported Fire Ants. USDA/SEA publication AAT-S-21, April.
BATterham, P. AND MACKENZIE, S. W. 1980. A phenol oxidase polymorphism in Drosophila melanogaster. Genetica, 54, 121-125.

BERKELHAMER, R. C. 1983. Intraspecific genetic variation and haplodiploidy, eusocality, and polygyny in the Hymenoptera. Evolution, 37, 540-545.

BERLOCHER, S. H. 1984. Insect molecular systematics. Ann. Rev. Entomol., 29, 403-433.

BUCHER, G. E. 1959. Winter rearing of tent caterpillars, Malacosoma spp. (Lepidoptera:Lasiocampidae). Can. Entomol., 91, 411-416.

CAVENER, D. R. 1980. Genetics of male-specific glucose oxidase and the identification of other unusual hexose enzymes in Drosophila melanogaster. Biochem. Genet., 18, 929-937.

CHAKRABORTY, R. 1981. The distribution of the number of heterozygous loci in an individual in natural populations. Genetics, 98, 461-466.

CosTA, J. T. AND Ross, K. G. 1992. Seasonal decline in intracolony genetic relatedness in eastern tent catapillars: implications for social evolution. Behav. Ecol. Sociobiol. (in press).

CRESPI, B. J. 1991. Heterozygosity in the haplodiploid Thysanoptera. Evolution, 45, 458-464.

CROZIER, R. H. 1970. On the potential for genetic variability in haplo-diploidy. Genetica, 41, 551-556.

CROZIER, R. H., SMITH, B. H. AND CROZIER, Y. C. 1987. Relatedness and population structure of the primitively eusocial bee Lasioglossum zephyrum (Hymenoptera: Halictidae) in Kansas. Evolution, 41, 902-910.

GORMAN, G. C. AND RENZI, J. 1979. Genetic distance and heterozygosity estimates in electrophoretic studies: Effects of sample size. Copeia, 2, 242-249.

GRAUR, D. 1985. Gene diversity in Hymenoptera. Evolution, 39, 190-199.

HALLIDAY, R. B. 1979. Esterase variation at three loci in meat ants. J. Hered., 70, 57-61.

HAMILTON, W. D. 1964. The genetical evolution of social behavior. J. Theor. Biol., 7, 1-52.

HARRIS, H. AND HOPKINSON, D. A. 1976. Handbook of Enzyme Electrophoresis in Human Genetics. Elsevier/North Holland, New York.

HARRIS, H. AND HOPKINSON, D. A. 1977. Handbook of Enzyme Electrophoresis in Human Genetics (Suppl.). Elsevier/ North Holland, New York.

HEBERT, P. D. N. AND BEATON, M. J. 1989. Methodologies for Allozyme Analysis Using Cellulose Acetate Electrophoresis. Helena Laboratories, Beaumont, Texas.

JOHNSON, F. M., SCHAFFER, H. E., GILLASPY, J. E. AND ROCKWOOD, E. S. 1969. Isozyme genotype-environment relationships in natural populations of the harvester ant, Pogonomyrmex barbatus, from Texas. Biochem. Genet., 3, 429-450.

JOUVENAZ, D. P., ALLEN, G. E., BANKS, W. A. AND WOJCIK, D. P. 1977. A survey for pathogens of fire ants, Solenopsis spp., in the southeastern United States. Florida Entomol., 60, 275-279.

METCALF, R. A., MARLIN, J. C. AND WHITT, G. S. 1975. Low levels of genetic heterozygosity in Hymenoptera. Nature, 257, 792-794. 
MiCHOD, R. E. 1982. The theory of kin selection. Ann. Rev. Ecol. Syst., 13, 23-55.

MITTON, J. B. AND PIERCE, B. A. 1980 . The distribution of individual heterozygosity in natural populations. Genetics, 95, 1043-1054.

MURPHY, R. W., SITES, J. W., BUTH, D. G. AND HAUFLER, C. H. 1990. Proteins I. Isozyme electrophoresis. In: Hillis, D. M. and Moritz, C. (eds) Molecular Systematics. Sinauer Associates, Sunderland, MA.

NEI, M. 1978. Estimation of average heterozygosity and genetic distance from a small number of individuals. Genetics, 89, 583-590.

NEI, M. 1987. Molecular Evolutionary Genetics. Columbia University Press, New York.

NEI, M. AND ROYCHOUDHURY, A. K. 1974. Sampling variances of heterozygosity and genetic distance. Genetics, 76, 379-390.

PACKER, L. AND OWEN, R. E. 1990. Allozyme variation, linkage disequilibrium and diploid male production in a primitively social bee Augochlorella striata (Hymenoptera: Halictidae). Heredity, 65, 241-248.

PACKER, L. AND OWEN, R. E. 1992. Variable enzyme systems in the Hymenoptera. Biochem. Syst. Ecol., 20, 1-7.

PAMILO, P. AND CROZIER, R. H. 1981. Genic variation in male haploids under deterministic selection. Genetics, 98, 199-214.

PAMILO, P., VARVIO-AHO, s.-L, AND PEKKARINEN, A. 1978. Low enzyme gene variability in Hymenoptera as a consequence of haplodiploidy. Hereditas, 88, 93-99.

PASTEUR, N., PASTEUR, G., BONHOMME, F., CATALAN, J. AND BRITTONDaVIdian, J. 1988. Practical Isozyme Genetics. John Wiley and Sons, New York.

QAVI, H. AND KIT, s. 1980. Electrophoretic patterns of aminoacylase $(A c y-1)$ isozymes in vertebrate cells and histochemical procedure for detecting Acy-1 activity. Biochem. Genet., 18, 669-679.

RICHARDSON, B. J., BAVERSTOCK, P. R. AND ADAMS, M. 1986. Allozyme Electrophoresis: A Handbook for Animal Systematics and Population Studies. Academic Press, Sydney, Australia.

RIDLEY, M. 1983. The Explanation of Organic Diversity. Clarendon Press, Oxford.
RIDLEY, M. 1989. Why not to use species in comparative tests. J. Theor. Biol., 136, 361-364.

ROSS, K. G. AND CARPENTER, J. M. 1991. Population genetic structure, relatedness, and breeding systems. In: Ross, K. G. and Matthews, R. W. (eds) The Social Biology of Wasps. Cornell University Press, Ithaca, NY

ROSS, K. G. AND FLETCHER, D. J. C. 1985. Comparative study of genetic and social structure in two forms of the fire ant Solenopsis invicta (Hymenoptera: Formicidae). Behav. Ecol. Sociobiol., 17, 349-356.

ROSS, K. G., FLETCHER, D. J. C. AND MAY, B. 1985. Enzyme polymorphisms in the fire ant, Solenopsis invicta (Hymenoptera: Formicidae). Biochem. Syst. Ecol., 13, 29-33.

ROSS, K. G. AND MATTHEWS, R. W. 1989. Population genetic structure and social evolution in the sphecid wasp, Microstigmus comes. Am. Nat., 134, 574-598.

ROSS, K. G. AND TRAGER, J. C. 1990 . Systematics and population genetics of fire ants (Solenopsis saevissima complex) from Argentina. Evolution, 44, 2113-2134.

ROSS, K. G., VARGO, E. L. AND FLETCHER, D. J. C. 1987. Comparative biochemical genetics of three fire ant species in North America, with special reference to the two social forms of Solenopsis invicta (Hymenoptera: Formicidae). Evolution, 41, 979-990.

SCHWARZ, M. P. 1988. Local resource enhancement and sex ratios in a primitively social bee. Nature, 331, 346-348.

SIMON, C. AND ARCHIE, J. 1985. An empirical demonstration of the lability of heterozygosity estimates. Evolution, 39, 463-467.

SINGH, R. S. AND RHOMBERG, L. R. 1987. A comparative study of genic variation in natural populations of Drosophila melanogaster II. Estimates of heterozygosity and patterns of geographic differentiation. Genetics, 117, 255-271.

SNYDER, T. P. 1974. Lack of allozyme variability in three bee species. Evolution, 28, 687-688.

WADE, M. J. 1985. The influence of multiple inseminations and multiple foundresses on social evolution. J. Theor. Biol., 112, 109-121.

WAGNER, R. P. AND SELANDER, R. K. 1974. Isozymes in insects and their significance. Ann. Rev. Entomol., 19, 117-138.

WEIR, B. s. 1990. Genetic Data Analysis. Sinauer Associates, Sunderland, MA.

Appendix 1 Summary of electrophoretic markers studied in Solenopsis invicta

\begin{tabular}{lllllll}
\hline Locus & $\begin{array}{l}\text { EC } \\
\text { number }\end{array}$ & $h_{\exp }$ & $\begin{array}{l}\text { Number } \\
\text { of alleles }\end{array}$ & $\begin{array}{l}\text { Source } \\
\text { material* }\end{array}$ & $\begin{array}{l}\text { Buffer } \\
\text { system } \dagger\end{array}$ & $\begin{array}{l}\text { Stain } \\
\text { reference } \neq\end{array}$ \\
\hline Aat -1 & 2.6 .1 .1 & 0 & 1 & 1,2 & $\mathrm{M}$ & 1 \\
Aat -2 & 2.6 .1 .1 & 0.18 & 2 & $1,3 \mathrm{a}, 4 \mathrm{~b}$ & $\mathrm{M}$ & 1 \\
Acoh-1 & 4.2 .1 .3 & 0.25 & 2 & $2,3 \mathrm{~b}$ & 4 & 1 \\
Acoh-4 & 4.2 .1 .3 & 0 & 1 & 2 & $\mathrm{C}$ & 1 \\
Acoh-5 & 4.2 .1 .3 & 0.27 & 2 & $2,4 \mathrm{a}, 4 \mathrm{~b}$ & 4 & 1 \\
Acp -2 & 3.1 .3 .2 & 0 & 1 & 2 & $\mathrm{C}$ & 2 \\
Acy-1 & 3.5 .1 .14 & 0.23 & 2 & $1,3 \mathrm{a}, 4 \mathrm{a}, 4 \mathrm{~b}$ & $\mathrm{M}$ & 6 \\
Adh-1 & 1.1 .1 .1 & 0 & 1 & 1,2 & $\mathrm{R}$ & 1 \\
Adh -2 & 1.1 .1 .1 & 0 & 1 & $3 \mathrm{a}, 4 \mathrm{a}$ & $\mathrm{R}$ & 1 \\
Adh-3 & 1.1 .1 .1 & 0 & 1 & $4 \mathrm{a}$ & $\mathrm{M}$ & 1
\end{tabular}


Appendix 1 Continued

\begin{tabular}{|c|c|c|c|c|c|c|}
\hline Locus & $\begin{array}{l}\text { EC } \\
\text { number }\end{array}$ & $h_{\exp }$ & $\begin{array}{l}\text { Number } \\
\text { of alleles }\end{array}$ & $\begin{array}{l}\text { Source } \\
\text { material* }\end{array}$ & $\begin{array}{l}\text { Buffer } \\
\text { system } \dagger\end{array}$ & $\begin{array}{l}\text { Stain } \\
\text { reference } \neq\end{array}$ \\
\hline$A k-1$ & 2.7 .4 .3 & 0 & 1 & $3 a, 4 a$ & $\mathrm{C}$ & 1 \\
\hline$A k-3$ & 2.7 .4 .3 & 0 & 1 & 2 & $\mathrm{C}$ & 1 \\
\hline$A k-4$ & 2.7 .4 .3 & 0 & 1 & $4 a$ & $\mathrm{C}$ & 1 \\
\hline Alp & 3.1.3.1 & 0 & 1 & 1 & $\mathrm{C}$ & 1 \\
\hline$A m y$ & 3.2.1.1 & 0 & 1 & $3 a, 4 a$ & $\mathbf{R}$ & 7 \\
\hline$A o$ & 1.2.3.1 & 0 & 1 & $3 a, 4 a$ & $\mathbf{R}$ & 1 \\
\hline$A p k$ & 2.7 .3 .3 & 0 & 1 & $1,2,3 a, 4 a, 4 b$ & $\mathbf{R}$ & $1 \S$ \\
\hline$A r s$ & 3.1.6.1 & 0 & 1 & 2 & 4 & 3 \\
\hline $\mathrm{Ca}-1$ & 4.2.1.1 & 0.46 & 2 & $4 b$ & $\mathbf{R}$ & 1 \\
\hline $\mathrm{Ca}-2$ & 4.2.1.1 & 0 & 1 & $3 b, 4 b$ & $\mathbf{R}$ & 1 \\
\hline $\mathrm{Ca}-3$ & 4.2.1.1 & 0 & 1 & $3 a, 4 a, 4 b$ & 4 & 2 \\
\hline$C a-4$ & 4.2.1.1 & 0.45 & 2 & 2 & 4 & 2 \\
\hline $\mathrm{Ca}-5$ & 4.2.1.1 & 0 & 1 & 2 & 4 & 2 \\
\hline $\mathrm{Ca}-6$ & 4.2.1.1 & 0 & 1 & $4 a$ & $\mathrm{C}$ & 2 \\
\hline Cat -2 & 1.11 .1 .6 & 0 & 1 & 1 & $\mathbf{R}$ & 4 \\
\hline Dasox & 1.4.3.1 & 0 & 1 & $3 b$ & $\mathbf{M}$ & 13 \\
\hline$D d h-1$ & 1.8 .1 .4 & 0.40 & 2 & 1 & $\mathrm{C}$ & 1 \\
\hline$D d h-2$ & 1.8.1.4 & 0 & 1 & $2,4 \mathrm{~b}$ & 4 & 1 \\
\hline Eno & 4.2.1.11 & 0 & 1 & $1,3 b$ & $\mathbf{M}$ & 1 \\
\hline Est-1 & 3.1.1.1 & 0 & 1 & $2,4 \mathrm{a}$ & $\mathrm{C}$ & 2 \\
\hline Est-2 & 3.1.1.1 & 0 & 1 & $2,3 a, 4 a$ & $\mathrm{C}$ & 2 \\
\hline Est-4 & 3.1.1.1 & 0.50 & 2 & $1,3 a, 4 a$ & $\mathrm{C}$ & 8 \\
\hline Est-6 & 3.1.1.1 & 0.64 & 4 & 2 & $\mathrm{C}$ & 1 \\
\hline$F b a$ & 4.1 .2 .13 & 0 & 1 & $2,3 \mathrm{a}$ & $\mathrm{C}$ & 2 \\
\hline$F b p-1$ & 3.1.3.11 & 0 & 1 & 2 & $\mathbf{M}$ & 1 \\
\hline$F b p-2$ & 3.1.3.11 & 0 & 1 & $1,3 a, 4 a$ & $\mathbf{M}$ & 1 \\
\hline$F k-1$ & 2.7.1.4 & 0 & 1 & $2,3 a, 4 a, 4 b$ & $\mathbf{R}$ & 2 \\
\hline Fumh-1 & 4.2.1.2 & 0 & 1 & $3 \mathrm{a}$ & $\mathrm{C}$ & 1 \\
\hline Fumh-2 & 4.2.1.2 & 0 & 1 & $4 a$ & $\mathbf{M}$ & 1 \\
\hline G3pdh-1 & 1.1.1.8 & 0.46 & 2 & $3 a, 4 a$ & $\mathrm{C}$ & 1 \\
\hline G3pdh-2 & 1.1.1.8 & 0 & 1 & $2,3 \mathrm{a}$ & $\mathrm{C}$ & 1 \\
\hline$\beta-G a$ & 3.2 .1 .30 & 0 & 1 & $4 b$ & $\mathrm{R}$ & 2 \\
\hline$\alpha-G a l$ & 3.2.1.22 & 0 & 1 & $3 a$ & $\mathbf{R}$ & 3 \\
\hline$\beta-G a l-1$ & 3.2 .1 .23 & 0 & 1 & 1 & $\mathbf{R}$ & 1 \\
\hline$\beta-G a l-2$ & 3.2 .1 .23 & 0.03 & 2 & 1 & $\mathbf{R}$ & 1 \\
\hline$\beta$-Gala & 3.2 .1 .53 & 0.03 & 2 & 1 & $\mathbf{R}$ & 2 \\
\hline Gapdh & 1.2.1.12 & 0 & 1 & $2,3 a, 4 b$ & $\mathrm{C}$ & 2 \\
\hline Gcdh & 1.1.1.118 & 0 & 1 & $4 b$ & $\mathbf{M}$ & 1 \\
\hline$G d a$ & 3.5.4.3 & 0 & 1 & 2 & $\mathbf{M}$ & 2 \\
\hline Glo-1 & 4.4.1.5 & 0 & 1 & $3 a$ & 4 & 1 \\
\hline$\beta$-Glur & 3.2.1.31 & 0 & 1 & 2 & $\mathbf{R}$ & 1 \\
\hline$\alpha-G l u s-1$ & 3.2 .1 .20 & 0 & 1 & 1 & 4 & 3 \\
\hline$\alpha-G l u s-2$ & 3.2 .1 .20 & 0 & 1 & 2 & 4 & 3 \\
\hline Gndh & 1.1.99.3 & 0 & 1 & $1,2,3 \mathrm{a}$ & $\mathbf{R}$ & 9 \\
\hline$G p-0$ & -.-.-.- & 0 & 1 & $3 a, 4 a$ & $\mathbf{M}$ & 5 \\
\hline$G p-I$ & -.-.-.- & 0 & 1 & $3 a, 4 a$ & $\mathbf{M}$ & 5 \\
\hline$G p-2$ & -.-.-.- & 0 & 1 & $4 a$ & $\mathbf{M}$ & 5 \\
\hline$G p-3$ & -.-.-.- & 0.06 & 2 & $3 a, 4 b$ & $\mathbf{M}$ & 5 \\
\hline$G p-4$ & -.-.-.- & 0 & 1 & 2 & $\mathbf{M}$ & 5 \\
\hline$G p-5$ & -.-.-.- & 0.39 & 2 & $4 a$ & $\mathrm{C}$ & 5 \\
\hline$G p-6$ & -.-.-.- & 0 & 1 & $4 a$ & $\mathrm{C}$ & 5 \\
\hline$G p-7$ & -.-.-.- & 0 & 1 & $4 a$ & $\mathrm{C}$ & 5 \\
\hline$G p-8$ & -..-..- & 0 & 1 & $4 a$ & $\mathrm{C}$ & 5 \\
\hline$G p i$ & 5.3.1.9 & 0 & 1 & $1,2,3 a, 3 b, 4 a, 4 b$ & 4 & 1 \\
\hline
\end{tabular}


Appendix 1 Continued

\begin{tabular}{|c|c|c|c|c|c|c|}
\hline Locus & $\begin{array}{l}\text { EC } \\
\text { number }\end{array}$ & $h_{\exp }$ & $\begin{array}{l}\text { Number } \\
\text { of alleles }\end{array}$ & $\begin{array}{l}\text { Source } \\
\text { material* }\end{array}$ & $\begin{array}{l}\text { Buffer } \\
\text { system } \dagger\end{array}$ & $\begin{array}{l}\text { Stain } \\
\text { reference }\end{array}$ \\
\hline$G r$ & 1.6 .4 .2 & 0 & 1 & $1,4 \mathrm{~b}$ & M & 1 \\
\hline Gtdh-3 & 1.4.1.3 & 0 & 1 & $4 a, 4 b$ & $\mathrm{R}$ & 1 \\
\hline Gtdh-4 & 1.4.1.3 & 0 & 1 & $2,4 \mathrm{~b}$ & $\mathrm{C}$ & 1 \\
\hline Haox-3 & 1.1.3.15 & 0 & 1 & $4 a$ & $\mathrm{C}$ & 2 \\
\hline$H b d h-2$ & 1.1.1.30 & 0 & 1 & $1,4 b$ & $\mathrm{R}$ & 1 \\
\hline$H k-2$ & 2.7 .1 .1 & 0 & 1 & $3 a, 4 a$ & $\mathbf{R}$ & 1 \\
\hline$H k-3$ & 2.7.1.1 & 0.03 & 2 & 1 & $\mathrm{R}$ & 1 \\
\hline$H k-4$ & 2.7.1.1 & 0 & 1 & $2,3 a, 4 a$ & $\mathbf{R}$ & 1 \\
\hline$H k-5$ & 2.7.1.1 & 0 & 1 & $4 b$ & $\mathrm{C}$ & 1 \\
\hline Iddh-1 & 1.1 .1 .14 & 0 & 1 & $2,4 a$ & $\mathrm{C}$ & 1 \\
\hline$I d d h-2$ & 1.1.1.14 & 0 & 1 & 2 & $\mathrm{C}$ & 1 \\
\hline$I d h-1$ & 1.1.1.42 & 0 & 1 & $4 a$ & 4 & 1 \\
\hline$I d h-2$ & 1.1 .1 .42 & 0 & 1 & $2,3 a$ & $\mathbf{R}$ & 1 \\
\hline$I d h-3$ & 1.1 .1 .42 & 0 & 1 & $4 a$ & 4 & 1 \\
\hline Lap-1 & 3.4 .11 .4 & 0.09 & 2 & $2,3 a, 4 a$ & $\mathrm{R}$ & 2 \\
\hline Lap-3 & 3.4 .11 .4 & 0 & 1 & 2 & $\mathrm{R}$ & 2 \\
\hline$L d h-1$ & 1.1.1.27 & 0 & 1 & $4 a, 4 b$ & $\mathrm{C}$ & 1 \\
\hline$L d h-2$ & 1.1 .1 .27 & 0 & 1 & $2,3 \mathrm{a}$ & $\mathrm{C}$ & 1 \\
\hline$\alpha-M a n$ & 3.2 .1 .24 & 0.03 & 2 & 2 & $\mathbf{R}$ & 2 \\
\hline$M d h-1$ & 1.1.1.37 & 0 & 1 & $3 a, 3 b$ & 4 & 1 \\
\hline Mdhp-1 & 1.1.1.40 & 0.06 & 2 & $2,3 a$ & C & 1 \\
\hline$M d h p-2$ & 1.1.1.40 & 0 & 1 & $1,2,3 \mathrm{a}$ & $\mathrm{C}$ & $1 \pi$ \\
\hline$M p i$ & 5.3.1.8 & 0 & 1 & $1,4 a$ & $\mathrm{R}$ & 1 \\
\hline Odh & 1.1 .1 .73 & 0 & 1 & $3 a, 4 a$ & $\mathrm{C}$ & $1^{* *}$ \\
\hline$P e p(g l)$ & 3.4.11.- & 0 & 1 & $1,2,3 a$ & $\mathrm{R}$ & $1^{++}$ \\
\hline$P e p(p a p)-1$ & 3.4.11.- & 0 & 1 & $1,2,3 \mathrm{a}, 4 \mathrm{a}$ & $\mathrm{R}$ & $1 \dagger \dagger$ \\
\hline$P e p(p a p)-2$ & 3.4.11.- & 0 & 1 & $1,2,4 \mathrm{a}$ & $\mathrm{R}$ & $1 \mathrm{t \dagger}$ \\
\hline Per & 1.11.1.7 & 0 & 1 & $4 a$ & $\mathrm{C}$ & $10 \S \S$ \\
\hline Pgam-1 & 5.4 .2 .1 & 0 & 1 & 1 & 4 & 1 \\
\hline Pgam-2 & 5.4.2.1 & 0 & 1 & $4 a$ & M & 1 \\
\hline$P g d h-2$ & 1.1 .1 .44 & 0 & 1 & $2,4 a$ & $\mathrm{C}$ & 1 \\
\hline Pgdh-3 & 1.1.1.44 & 0 & 1 & 1 & $\mathrm{C}$ & 1 \\
\hline$P g k$ & 2.7.2.3 & 0 & 1 & $4 a$ & M & 1 \\
\hline Pgm-1 & 5.4.2.2 & 0.22 & 2 & $1,2,3 \mathrm{a}, 4 \mathrm{a}, 4 \mathrm{~b}$ & $\mathrm{C}$ & 1 \\
\hline Pgm-2 & 5.4 .2 .2 & 0 & 1 & $2,4 b$ & $\mathrm{C}$ & 1 \\
\hline Pgm-3 & 5.4 .2 .2 & 0.37 & 2 & 2 & $\mathrm{C}$ & 1 \\
\hline$P g m-4 \pi \pi$ & 5.4 .2 .2 & 0.43 & 2 & 1 & $\mathrm{C}$ & 1 \\
\hline Phox & 1.10 .3 .1 & 0 & 1 & $3 a, 4 b$ & $\mathbf{R}$ & 11 \\
\hline$P k-1$ & 2.7.1.40 & 0 & 1 & $3 a, 4 a$ & $\mathbf{R}$ & 1 \\
\hline$P k-2$ & 2.7 .1 .40 & 0 & 1 & 2 & 4 & 1 \\
\hline$S k d h-1$ & 1.1.1.25 & 0 & 1 & 2 & $\mathrm{C}$ & 4 \\
\hline$S k d h-2$ & 1.1 .1 .25 & 0 & 1 & $4 b$ & $\mathrm{C}$ & 4 \\
\hline Sod-2 & 1.15 .1 .1 & 0 & 1 & $3 a, 4 a, 4 b$ & $\mathbf{M}$ & 2 \\
\hline Treh-1 & 3.2.1.28 & 0 & 1 & 1 & $\mathrm{C}$ & 12 \\
\hline Treh-2 & 3.2 .1 .28 & 0 & 1 & $4 \mathrm{~b}$ & $\mathbf{R}$ & 10 \\
\hline Ugpp-2 & 2.7 .7 .9 & 0 & 1 & $2,3 a$ & $\mathbf{M}$ & 3 \\
\hline
\end{tabular}

§Phospho-arginine substituted for phosphocreatine as substrate.

IW Without $\mathrm{MgCl}_{2}$ and adjust stain buffer to $\mathrm{pH} 8.0$.

**With 2-octanol as substrate.

${ }^{++}$With glycyl-leucine as substrate.

††With phenylalanyl-proline as substrate.

$\S \S$ Listed as haemoglobin.

กภDenotes locus with null allele.
* $1=$ fourth instar worker larvae; $2=$ worker pupae; $3=$ adult workers; 4 =adult queens; $a=$ thorax (mesosoma); b = gaster.

$\dagger \mathrm{M}=\mathrm{pH} 8.6$ tris-borate-EDTA continuous buffer system; $\mathrm{C}=\mathrm{pH} \quad 6.0$ amine-citrate (morpholine) continuous buffer system; $4=\mathrm{pH} 6.5$ tris-citrate continuous buffer system; $\mathrm{R}=\mathrm{pH} 8.2$ lithium-borate/ tris-citrate discontinuous buffer system. See Murphy et al (1990).

$\ddagger 1=$ Richardson et al., 1986; $2=$ Pasteur et al., 1988; 3= Harris \& Hopkinson, 1976; 4 = Murphy et al., 1990; 5=B. May, unpublished data; 6= Qavi \& Kit, 1980; $7=$ Ashton, 1965; $8=$ Johnson et al., 1969; $9=$ Cavener, 1980; $10=$ Hebert \& Beaton, $1989 ; 11=$ Batterham \& MacKenzie, $1980 ; \quad 12=$ C. R. Hughes, unpublished data; $13=$ Harris \& Hopkinson, 1977 
Appendix 2 Summary of electrophoretic markers studied in Malacosoma americanum

\begin{tabular}{|c|c|c|c|c|c|}
\hline Locus & $\begin{array}{l}\text { EC } \\
\text { number }\end{array}$ & $h_{\exp }$ & $\begin{array}{l}\text { Number } \\
\text { of alleles }\end{array}$ & $\begin{array}{l}\text { Buffer } \\
\text { system* }\end{array}$ & $\begin{array}{l}\text { Stain } \\
\text { reference } \dagger\end{array}$ \\
\hline Aat-1 & 2.6.1.1 & 0.50 & 4 & $\mathrm{C}$ & 1 \\
\hline Aat -2 & 2.6.1.1 & 0.01 & 2 & $\mathrm{C}$ & 1 \\
\hline Acoh-2 & 4.2 .1 .3 & 0 & 1 & 4 & 1 \\
\hline Adh-1 & 1.1.1.1 & 0 & 1 & 4 & 1 \\
\hline$A d h-3$ & 1.1.1.1 & 0 & 1 & 4 & 1 \\
\hline$A k$ & 2.7.4.3 & 0 & 1 & $\mathrm{C}$ & 1 \\
\hline$D d h-1$ & 1.8.1.4 & 0 & 1 & $\mathrm{R}$ & 1 \\
\hline Eno & 4.2.1.11 & 0 & 1 & $\mathrm{C}$ & 1 \\
\hline Est & 3.1.1.1 & 0 & 1 & M & 2 \\
\hline$F b p-2$ & 3.1.3.11 & 0 & 1 & M & 1 \\
\hline G3pdh-1 & 1.1.1.8 & 0 & 1 & $\mathrm{C}$ & 1 \\
\hline$\beta$-Gala & 3.2 .1 .53 & 0.07 & 3 & C & 2 \\
\hline$\beta$-Glur & 3.2 .1 .31 & 0 & 1 & $\mathrm{R}$ & 1 \\
\hline$\alpha-G l u s-1$ & 3.2 .1 .20 & 0.38 & 5 & $\mathrm{C}$ & 3 \\
\hline Gndh & 1.1.99.3 & 0 & 1 & $\mathrm{C}$ & 6 \\
\hline$G p-1$ & -...-. & 0 & 1 & $\mathrm{R}$ & 5 \\
\hline$G p-2$ & -.-.-- & 0 & 1 & $\mathrm{R}$ & 5 \\
\hline Gpi & 5.3.1.9 & 0.48 & 11 & $\mathrm{C}$ & 1 \\
\hline$G r$ & 1.6 .4 .2 & 0 & 1 & $\mathbf{M}$ & 1 \\
\hline$H b d h$ & 1.1.1.30 & 0.65 & 7 & $\mathrm{C}$ & 1 \\
\hline$H k$ & 2.7.1.1 & 0 & 1 & $\mathrm{C}$ & 1 \\
\hline $1 d h-1$ & 1.1.1.42 & 0.07 & 2 & $\mathrm{C}$ & 1 \\
\hline$I d h-2$ & 1.1.1.42 & 0 & 1 & $\mathrm{C}$ & 1 \\
\hline Lap & 3.4.11.4 & 0 & 1 & $\mathrm{C}$ & 2 \\
\hline$\alpha-M a n$ & 3.2.1.24 & 0 & 1 & $\mathrm{R}$ & 2 \\
\hline$M d h-2$ & 1.1.1.37 & 0.04 & 2 & $\mathrm{C}$ & 1 \\
\hline Mdhp-1 & 1.1.1.40 & 0 & 1 & $\mathrm{C}$ & 1 \\
\hline Odh & 1.1.1.73 & 0 & 1 & $\mathrm{C}$ & $1 \ddagger$ \\
\hline$P e p(g l)$ & 3.4.11.- & 0 & 1 & $\mathrm{R}$ & $1 \S$ \\
\hline$P e p(p a p)-1$ & 3.4.11.- & 0.48 & 7 & $\mathrm{C}$ & $1 \pi$ \\
\hline Pgdh & 1.1.1.44 & 0 & 1 & $\mathrm{C}$ & 1 \\
\hline Pgm-1 & 5.4.2.2 & 0.38 & 5 & 4 & 1 \\
\hline Pgm-2 & 5.4.2.2 & 0.34 & 5 & 4 & 1 \\
\hline$P k$ & 2.7 .1 .40 & 0 & 1 & $\mathbf{M}$ & 1 \\
\hline Sod & 1.15.1.1 & 0 & 1 & $\mathrm{C}$ & 2 \\
\hline Tpi & 5.3.1.1 & 0 & 1 & $\mathrm{C}$ & 4 \\
\hline$X d h$ & 1.1 .1 .204 & 0 & 1 & $\mathrm{R}$ & 4 \\
\hline
\end{tabular}

${ }^{*} \mathrm{M}=\mathrm{pH} 8.6$ tris-borate-EDTA continuous buffer system; $\mathrm{C}=\mathrm{pH} 6.0$ amine-citrate (morpholine) continuous buffer system; $4=\mathrm{pH} 6.5$ tris-citrate continuous buffer system; $\mathrm{R}=\mathrm{pH} 8.2$ lithium-borate/tris-citrate discontinuous buffer system. See Murphy et al. $(1990)$.

$\dagger 1$ = Richardson et al., 1986; 2 = Pasteur et al., 1988; 3 = Harris \& Hopkinson, $1976 ; 4=$ Murphy et al., 1990; 5 =B. May, unpublished data; $6=$ Cavener, 1980. $\neq$ With 2-octanol as substrate.

$\S$ With glycyl-leucine as substrate.

TWith phenylalanyl-proline as substrate. 